\title{
Fucoidan downregulates insulin-like growth factor-I receptor levels in HT-29 human colon cancer cells
}

\author{
$\mathrm{IN}-\mathrm{HYE} \mathrm{KIM}^{1}$ and TAEK-JEONG NAM ${ }^{1,2}$ \\ ${ }^{1}$ Cell Biology Laboratory, Institute of Fisheries Sciences, Pukyong National University, Busan 46041; ${ }^{2}$ Department of \\ Food Science and Nutrition, Pukyong National University, Busan 48513, Republic of Korea
}

Received August 29, 2017; Accepted December 29, 2017

DOI: $10.3892 /$ or.2018.6193

\begin{abstract}
Fucoidan, a sulfated polysaccharide present in brown seaweed, has demonstrated anticancer activity in lung, breast, liver and colon cells. The insulin-like growth factor (IGF) signaling pathway regulates growth in HT-29 cells through the insulin receptor substrate-1 (IRS-1)/phosphatidylinositol 3-kinase (PI3K)/protein kinase B (AKT) and Ras/Raf/extracellular signal-regulated kinase (ERK) pathways. The aim of the present study was to investigate whether fucoidan downregulates the IGF-IR signaling pathway in HT-29 human colon cancer cells. Fucoidan treatment $(0-1,000 \mu \mathrm{g} / \mathrm{ml})$ was administered for $24 \mathrm{~h}$ in HT-29 cells. First, we investigated IRS-1/PI3K/AKT pathway-related protein expression levels following treatment with fucoidan $(0-500 \mu \mathrm{g} / \mathrm{ml})$ using western blot analysis. Fucoidan significantly inhibited the expression of IGF-IR, PTEN, PI3K and AKT as well as their phosphorylated forms (p-IRS-1, p-PI3K and p-AKT). Next, we investigated the effects of fucoidan on Ras/Raf/ERK pathway-related protein expression levels in HT-29 cells. Fucoidan significantly inhibited the expression of IGF-IR, Shc, Ras, SOS, Raf and MEK. HT-29 cells were then incubated in the presence of fucoidan $(0$ or $250 \mu \mathrm{g} / \mathrm{ml})$, and IGF-I $(10 \mathrm{nM})$ was added for 0 to $60 \mathrm{~min}$. Immunoprecipitation (IP) experiments showed that fucoidan inhibited IGF-I-induced phosphorylation of IGF-IR, PI3K, Shc (IP, IGF-IR), and phosphorylated IRS-1 and PI3K (IP, IRS-1) compared to the control group. Western blot analysis showed that fucoidan inhibited the expression of IGF-I-induced p-IGF-IR/IGF-IR and p-AKT/AKT, but not p-ERK/ERK. In conclusion, the inhibition of cell viability by fucoidan in HT-29 cells may be due to the downregulation of IGF-IR signaling through the main IRS-1/PI3K/AKT pathway. Fucoidan also partially impacted Ras/Raf signaling in the Ras/Raf/ERK pathway. Therefore, we suggest that fucoidan
\end{abstract}

Correspondence to: Professor Taek-Jeong Nam, Department of Food Science and Nutrition, Pukyong National University, 45 Yongso-ro, Nam-gu, Busan 48513, Republic of Korea E-mail: namtj@pknu.ac.kr

Key words: fucoidan, HT-29 colon cancer cell, IGF-IR, IRS-1, AKT may be a suitable candidate chemopreventive agent in HT-29 colon cancer cells.

\section{Introduction}

Colon cancer is the most commonly diagnosed cancer and one of the leading causes of deaths in the United States and worldwide $(1,2)$. It is the third most common cancer in men and the second most common cancer in women worldwide (2). Radiation treatment and chemotherapy are not therapeutically sufficient due to side effects and drug resistance (3). Several studies have shown close associations between colon cancer and dietary factors such as fruit, vegetables, and seaweeds containing a wide variety of phytochemicals. Some of these phytochemicals have been shown to protect cells from damage leading to cancer.

Fucoidan is a fucose-rich sulfated polysaccharide found in various species of brown seaweed (4-7). Fucoidan has been shown to exert various biological activities, including antioxidant, anti-inflammatory, anti-angiogenic, anti-coagulant, anti-bacterial, and anticancer effects (8-18). Studies have shown anticancer activities of fucoidan in lung, breast, liver, colon, prostate, and bladder cancer cells (19-23). Fucoidan has also been shown to induce tumor cell injury leading to growth arrest and tumor suppression via apoptosis and cell cycle arrest in various cancer cell types (24-29). Therefore, fucoidan shows promise as a new therapeutic compound for cancer treatment. Despite numerous studies showing the chemopreventive effects of fucoidan in several cancer models, its mechanism of action has not been fully elucidated.

The insulin-like growth factor (IGF) signaling system, consisting of ligands (IGF-I and IGF-II), growth factor receptors (IGF-IR and IGF-IIR), and IGF binding proteins (IGFBPs-1-6), regulates cell growth, proliferation, transformation, differentiation, migration and apoptosis $(30,31)$. IGFs play a vital role in the growth of various cancer cells, including colon cancer cells $(31,32)$. IGF-I and IGF-II mRNA levels are highly increased in colon cancer $(33,34)$. Ligand binding to IGF-IR triggers two main downstream signaling pathways, the insulin receptor substrate-1 (IRS-1)/phosphatidylinositol 3-kinase (PI3K)/protein kinase B (AKT) pathway and the Ras/Raf/extracellular signal-regulated kinase (ERK) pathway. The IRS-1/PI3K/AKT pathway is implicated in the transmission of cell survival signals, and the Ras/Raf/ERK 
pathway is implicated in receptor-mediated mitogenesis and transformation $(35,36)$.

In previous studies, fucoidan inhibited HT-29 cell proliferation by inducing apoptosis (23). In anti-colon cancer-related studies, the epidermal growth factor (EGF) pathway has been investigated, but no studies have investigated the IGF-I pathway (37). Therefore, in the present study, we examined whether fucoidan downregulates IGF-IR signaling in HT-29 cells.

\section{Materials and methods}

Preparation of fucoidan. Fucoidan purified from Fucus vesiculosus (cat. no. sc-255187) was purchased from Santa Cruz Biotechnology, Inc. (Dallas, TX, USA). Fucoidan was dissolved in RPMI-1640 medium (GenDEPOT, Inc., Barker, TX, USA) at concentrations of $0-1,000 \mu \mathrm{g} / \mathrm{ml}$.

Cell culture. HT-29 human colon adenocarcinoma cells (cat. no. 30038) were purchased from the Korean Cell Line Bank (Seoul, Korea). The cells were cultured in RPMI-1640 medium supplemented with $10 \%$ fetal bovine serum (FBS; GenDEPOT, Inc.) containing $50 \mu \mathrm{g} / \mathrm{ml}$ penicillin, $25 \mu \mathrm{g} / \mathrm{ml}$ amphotericin $\mathrm{B}$, and $50 \mu \mathrm{g} / \mathrm{ml}$ streptomycin, in an incubator with $5 \% \mathrm{CO}_{2}$ at $37^{\circ} \mathrm{C}$.

Cell proliferation assay. Cell proliferation was estimated using a Cyto X cell viability assay kit (LPS Solution, Daejeon, Korea). Cells were seeded in 96-well plates at a density of $4 \times 10^{4}$ cells/well and allowed to attach for $24 \mathrm{~h}$. Attached cells were treated with $62.5,125,250,500$ or $1,000 \mu \mathrm{g} / \mathrm{ml}$ of fucoidan in serum-free medium for $24 \mathrm{~h}$. The cell proliferation assay solution was added and incubated for $1 \mathrm{~h}$, and the absorbance of each well was measured at a wavelength of $450 \mathrm{~nm}$ using a FilterMax F5 microplate reader (Molecular Devices LLC, Sunnyvale, CA, USA).

Immunoprecipitation and western blot analysis. HT-29 cells were cultured with $0,62.5,125,250$, or $500 \mu \mathrm{g} / \mathrm{ml}$ of fucoidan for 24 h. Subsequently, cells were washed with phosphate-buffered saline (PBS) and lysed with extraction buffer (1\% Nonidet P-40, $1 \mathrm{mM}$ EDTA, $50 \mathrm{mM}$ Tris, $\mathrm{pH}$ 7.4, 0.25\% Na-deoxycholate, $150 \mathrm{mM} \mathrm{NaCl}, 1 \mathrm{mM}$ sodium orthovanadate, $1 \mu \mathrm{g} / \mathrm{ml}$ aprotinin, $1 \mu \mathrm{g} / \mathrm{ml}$ leupeptin, $1 \mu \mathrm{g} / \mathrm{ml}$ pepstatin $\mathrm{A}, 1 \mathrm{mM} \mathrm{NaF}$, and $1 \mathrm{mM}$ PMSF). The extracts were centrifuged at 9,750 $\mathrm{x} \mathrm{g}$ for $10 \mathrm{~min}$, and the supernatant was used for western blot analysis.

For immunoprecipitation (IP), cells were incubated for $24 \mathrm{~h}$ with 0 or $250 \mu \mathrm{g} / \mathrm{ml}$ of fucoidan, and $10 \mathrm{nM}$ of IGF-I (recombinant human IGF-I; Invitrogen Life Technologies, Frederick, MD, USA) was added. At $0,5,30$ or 60 min after the addition of IGF-I, the cell lysates were centrifuged at 9,750 x g for $10 \mathrm{~min}$. Supernatant $(0.90 \mathrm{mg}$ protein) were incubated with $3 \mu \mathrm{l}$ of anti-IGF-IR $\beta$ or IRS- 1 antibody overnight at $4^{\circ} \mathrm{C}$. Protein A-agarose beads (GenDEPOT, Inc.) were added to the lysate-antibody mix, which was then incubated for $4 \mathrm{~h}$ at $4^{\circ} \mathrm{C}$. The beads were washed 3 times with extraction buffer. The immunoprecipitates and total protein $(40 \mu \mathrm{g})$ were electrophoresed using $8-15 \%$ sodium dodecyl sulfate-polyacrylamide gel electrophoresis (SDS-PAGE) and transferred to polyvinylidene fluoride membrane (EMD Millipore, Billerica, MA, USA). Membranes were blocked with $1 \%$ bovine serum albumin

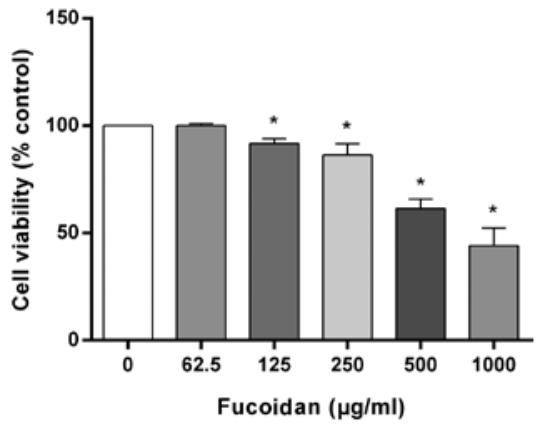

Figure 1. Fucoidan treatment induced death in HT-29 cells. HT-29 cells were seeded in 96-well plates at a density of $4 \times 10^{4}$ cells/well and subsequently treated with $0-1,000 \mu \mathrm{g} / \mathrm{ml}$ fucoidan for $24 \mathrm{~h}$. Data are presented as means \pm standard deviation (SD) of three independent experiments. Data were analyzed using one-way analysis of variance. ${ }^{*} \mathrm{P}<0.05$ vs. control.

(BSA; GenDEPOT, Inc.) in Tris-buffered saline-Tween-20 (TBS-T; 5 mM Tris- $\mathrm{HCl}, 20 \mathrm{mM}$ sodium chloride $\mathrm{pH} 7.4$, and $0.1 \%$ Tween-20) incubated with primary antibodies $(1: 1,000)$ in $1 \% \mathrm{BSA}$ in TBS-T with gentle shaking overnight at $4^{\circ} \mathrm{C}$. Membranes were washed twice for $15 \mathrm{~min}$ in TBS-T, and incubated with the corresponding horseradish peroxidase (HRP)-conjugated secondary antibodies $(1: 10,000)$ for $2 \mathrm{~h}$ at room temperature and washed again. Immunoreactive bands were detected using an enhanced chemiluminescence substrate (Advansta, Inc., Menlo Park, CA, USA) and visualized using the GeneSys imaging system (SynGene Synoptics, Ltd., London, UK). The following primary antibodies from Santa Cruz Biotechnology, Inc., and Invitrogen were used: anti-p-IGF-IR (sc-101703, anti-rabbit), anti-IGF-IR (sc-390130, anti-mouse), anti-phospho-tyrosine (PY99; sc-7020, anti-mouse), anti-p-IRS-1 (sc-17200, anti-goat), anti-IRS-1 (sc-185, anti-mouse), anti-p-AKT (sc-7985, anti-rabbit), anti-AKT (sc-8312, anti-rabbit), anti-p-PI3K (PA5-17387, anti-mouse), anti-PI3K (sc-374534, anti-mouse), anti-Ras (sc-520, anti-rabbit), anti-Raf (sc-227, anti-rabbit), anti-p-MEK (sc-81503, anti-mouse), anti-MEK (sc-81504, anti-mouse), anti-p-ERK (sc-7383, anti-mouse), anti-ERK (sc-292838, anti-rabbit), anti-SOS (sc-259, anti-rabbit), anti-Grb2 (sc-255, anti-rabbit), anti-Shc (sc-967, anti-mouse), anti-PTEN (sc-7974, anti-mouse), and anti- $\beta$-actin (sc-47778, anti-mouse). The secondary antibodies used were HRP-conjugated antimouse IgG (32430), anti-rabbit IgG (31460), and anti-goat IgG (31400) (all from Invitrogen Life Technologies).

Statistical analyses. The results are presented as means \pm standard deviation of three independent experiments. The difference in protein expression levels was determined by quantifying the density of the bands using ImageJ (NIH). Significant differences among multiple mean values were assessed using one-way or two-way analysis of variance followed by Bonferroni's multiple comparison test using GraphPad Prism 6 (GraphPad Software, Inc., La Jolla, CA, USA). P<0.05 was considered to indicate a statistically significant difference.

\section{Results}

Fucoidan induces cell death in HT-29 cells. To investigate the effects of fucoidan on cell viability, HT-29 cells were incubated 

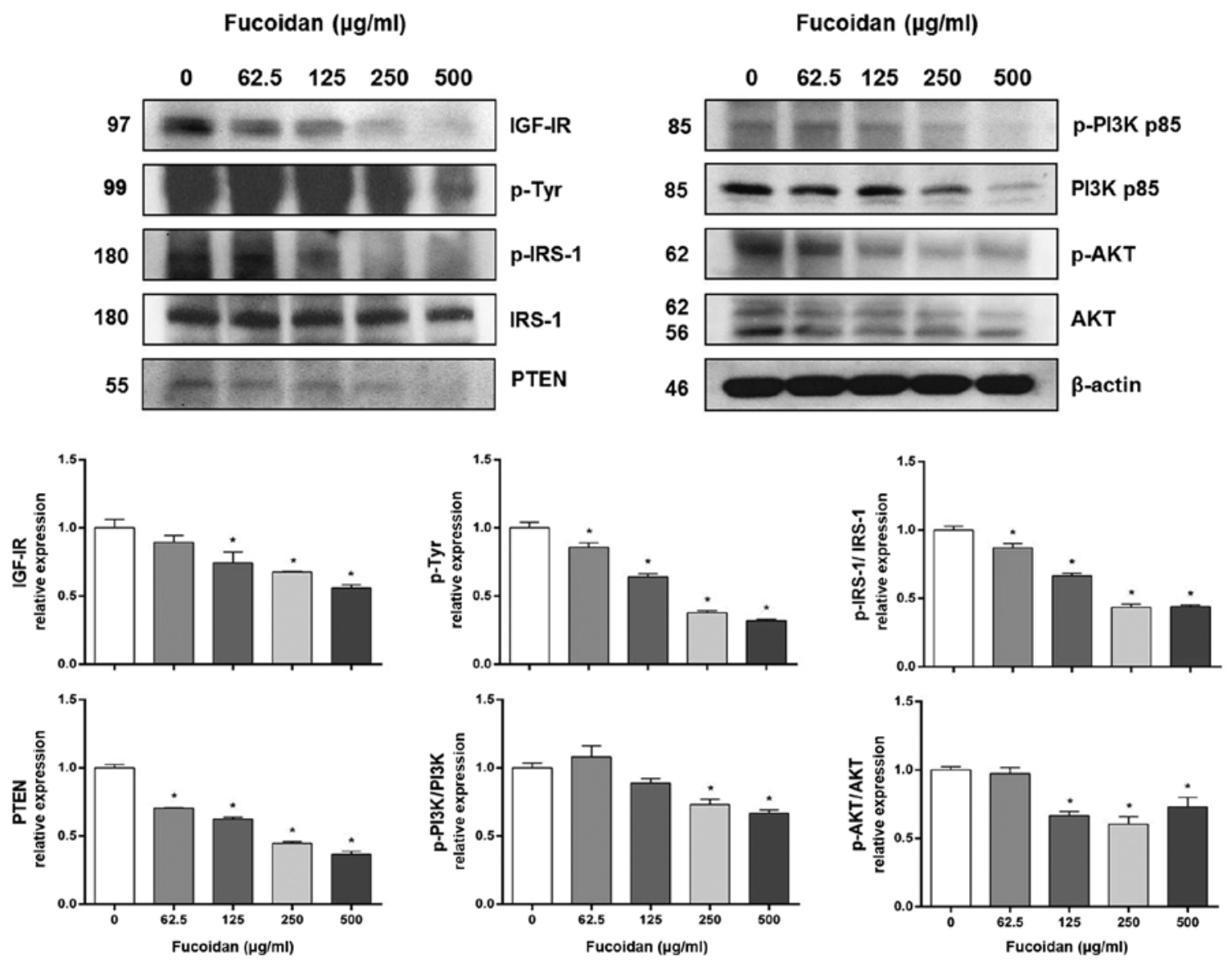

Figure 2. Fucoidan treatment reduces the levels of proteins in the IRS-1/PI3K/AKT pathway in HT-29 cells. HT-29 cells were incubated with various concentrations of fucoidan $(0-500 \mu \mathrm{g} / \mathrm{ml})$ for $24 \mathrm{~h}$. The protein expression levels of IGF-IR, IRS-1, PTEN, PI3K, and AKT were examined by western blot analysis. Data were analyzed using one-way analysis of variance. $\mathrm{P}<0.05$ vs. control. IRS-1, insulin receptor substrate-1; PI3K, phosphatidylinositol 3-kinase; AKT, protein kinase B; IGF, insulin-like growth factor. (Values at the left of the western blot indicate the molecular weights of the proteins in kDa).

with various concentrations $(0-1,000 \mu \mathrm{g} / \mathrm{ml})$ of fucoidan for $24 \mathrm{~h}$. Fucoidan treatment significantly decreased the viability of HT-29 cells in a concentration-dependent manner (Fig. 1). After treatment with $125,250,500$ and $1,000 \mu \mathrm{g} / \mathrm{ml}$ fucoidan, cell viability was significantly decreased to $91.7 \pm 2.3,86.3 \pm 5.3$, $61.5 \pm 4.4$ and $44.1 \pm 8.3 \%$, respectively.

Fucoidan reduces the levels of IRS-1/PI3K/AKT pathway-related proteins in HT-29 cells. IGFs signaling is known to affect cell survival, and IGF-I mRNA is increased in colon cancer cells $(33,34)$. Therefore, we investigated whether the IGF-IR signaling pathway is involved in fucoidan-induced cell death. First, we investigated IRS-1/PI3K/AKT pathway-related protein expression levels, one of the two main downstream IGF-IR signaling pathways. Fucoidan treatment significantly decreased the expression of IGF-IR, phospho-tyrosine andPTEN in HT-29 cells in a concentration-dependent manner (Fig. 2). Fucoidan treatment also significantly decreased the ratios of p-IRS-1/IRS-1, p-PI3K/PI3K and p-AKT/AKT expression.

Fucoidan reduces the levels of Ras/Raf/ERK pathwayrelated proteins in HT-29 cells. Next, we investigated Ras/Raf/ERK pathway-related protein expression levels, the other main IGF-IR downstream signaling pathway. Fucoidan treatment significantly decreased the expression of IGF-IR, phospho-tyrosine, Shc, Ras, SOS, Grb2, and Raf in HT-29 cells in a concentration-dependent manner (Fig. 3). Fucoidan treatment also significantly decreased the expression of $\mathrm{p}-\mathrm{MEK} / \mathrm{MEK}$, but not $\mathrm{p}-\mathrm{ERK} / \mathrm{ERK}$.

Fucoidan reduces IGF-I-induced IGF-IR activation of the IGF-IR signaling pathway. We examined whether fucoidan downregulates IGF-I-induced tyrosine phosphorylation of IGF-IR. HT-29 cells were treated for $24 \mathrm{~h}$ with 0 or $250 \mu \mathrm{g} / \mathrm{ml}$ fucoidan, and IGF-IR was stimulated with $10 \mathrm{nM}$ IGF-I for $0,5,30$, or $60 \mathrm{~min}$. Total cell lysates were prepared and immunoprecipitated using an IGF-IR $\beta$ antibody. The immune complexes were used in western blot analysis with an anti-phospho-tyrosine antibody (PY99). IGF-I induced tyrosine phosphorylation of IGF-IR at $5 \mathrm{~min}$, and tyrosine phosphorylation levels persisted at $60 \mathrm{~min}$ in control cells. Cells treated with fucoidan exhibited significantly inhibited IGF-IR $\beta$ phosphorylation up to $30 \mathrm{~min}$ after IGF-I stimulation (Fig. 4).

To investigate the association of the Shc and p85 subunits of PI3K with IGF-IR, we performed IP of cell lysates with an IGF-IR $\beta$ antibody and subsequent western blot analysis with p85 and Shc antibodies. IGF-I stimulated the association of the p85 regulatory subunit of PI3K with IGF-IR. Expression of the p85 regulatory subunit of PI3K in the control group 

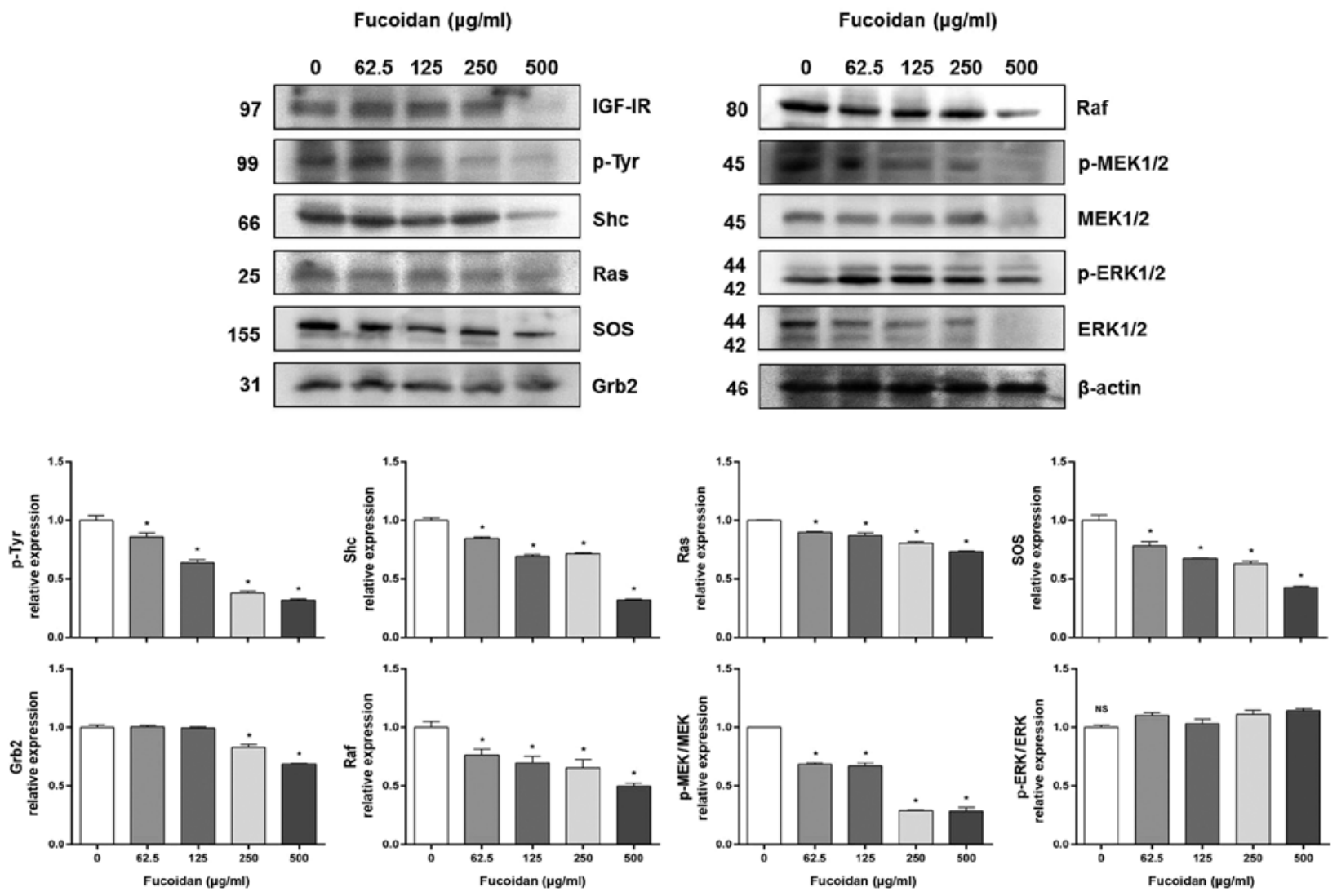

Figure 3. Fucoidan reduces the levels of proteins in the Ras/Raf/ERK pathway in HT-29 cells. HT-29 cells were incubated with various concentrations of fucoidan $(0-500 \mu \mathrm{g} / \mathrm{ml})$ for $24 \mathrm{~h}$. The protein expression levels of IGF-IR, Shc, Ras, SOS, Grb2, Raf, MEK, and ERK were examined by western blot analysis. Data were analyzed using one-way analysis of variance. "P $<0.05$ vs. control. ERK, extracellular signal-regulated kinase. (Values at the left of the western blot indicate the molecular weights of the proteins in $\mathrm{kDa}$ ).

was induced within $5 \mathrm{~min}$, but fucoidan treatment delayed its expression by up to $30 \mathrm{~min}$. IGF-I also stimulated the association of the Shc subunit with IGF-IR. The expression of She in the control cells was induced within $1 \mathrm{~min}$, but in cells treated with fucoidan, expression was induced at $5 \mathrm{~min}$.

Fucoidan reduces IGF-I-induced IRS-1 activation in the IGF-IR signaling pathway. We examined whether fucoidan downregulates IGF-I-induced tyrosine phosphorylation of IRS-1. HT-29 cells were treated for $24 \mathrm{~h}$ with 0 or $250 \mu \mathrm{g} / \mathrm{ml}$ fucoidan, and IGF-IR was stimulated with $10 \mathrm{nM}$ IGF-I for 0 , 5,30 , or $60 \mathrm{~min}$. Total cell lysates were prepared and immunoprecipitated using an IRS-1 antibody. The immune complexes were used in western blot analysis with anti-phospho-tyrosine antibody. IGF-I induced tyrosine phosphorylation of IRS-1 at $5 \mathrm{~min}$, and tyrosine phosphorylation levels persisted for $30 \mathrm{~min}$ in control cells. Treatment with fucoidan significantly inhibited the phosphorylation of IRS-1 for up to $60 \mathrm{~min}$ after IGF-I stimulation (Fig. 5).

To investigate the association of the $\mathrm{p} 85$ subunit of PI3K with IRS-1, we performed IP of cell lysates with an IRS-1 antibody and subsequent western blot analysis with a p85 antibody. IGF-I stimulated the association of the p85 regulatory subunit of PI3K and IRS-1 with IRS-1. Expression of the p85 regulatory subunit of PI3K and IRS-1 in control cells were stimulated within $5 \mathrm{~min}$, but fucoidan treatment delayed expression for up to $60 \mathrm{~min}$.

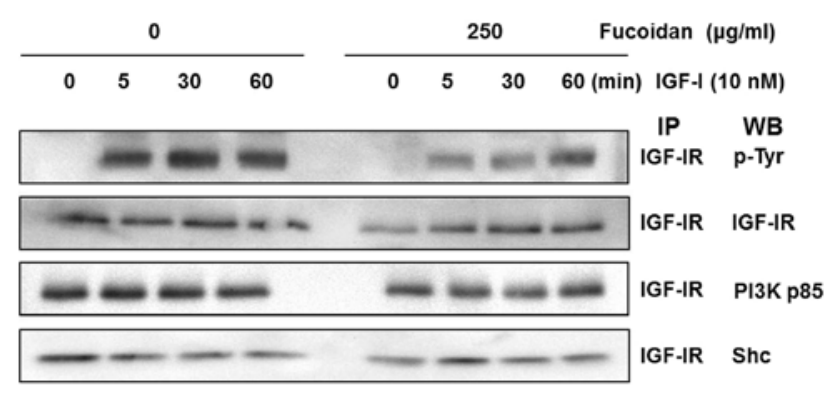

Figure 4. Fucoidan treatment reduces IGF-I-induced tyrosine phosphorylation of IGF-IR in HT-29 cells. HT-29 cells were incubated for $24 \mathrm{~h}$ with 0 or $250 \mu \mathrm{g} / \mathrm{ml}$ of fucoidan and lysed with or without stimulation with IGF-I $(10 \mathrm{nM})$ for $0,5,30$ or $60 \mathrm{~min}$. Total cell lysates $(0.90 \mathrm{mg}$ total protein) were incubated with anti-IGF-IR $\beta$ antibody and the immune complexes were precipitated with protein A-agarose beads. The immunoprecipitated proteins were analyzed with western blot analysis with antibodies against phosphotyrosine (PY99), IGF-IR, PI3K p85 or Shc. IGF, insulin-like growth factor; PI3K, phosphatidylinositol 3-kinase.

Fucoidan reduces IGF-I-induced activation of AKT in $H T-29$ cells. AKT and ERK1/2 are known to play vital roles in cell survival and are activated by IGF-I $(33,37,38)$. HT-29 cells were treated for $24 \mathrm{~h}$ with 0 or $250 \mu \mathrm{g} / \mathrm{ml}$ fucoidan, and IGF-IR was stimulated with $10 \mathrm{nM}$ IGF-I for $0,5,30$, or $60 \mathrm{~min}$. We investigated whether fucoidan inhibits IGF-I-induced phosphorylation of IGF-IR, AKT, and ERK, a downstream target of 


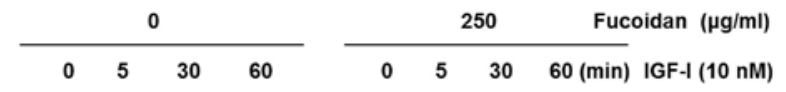

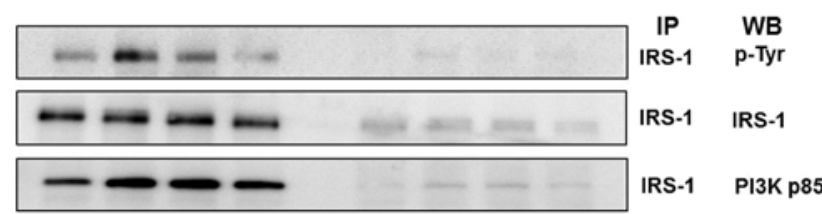

Figure 5. Fucoidan treatment reduces IGF-I-induced tyrosine phosphorylation of IRS-1 in HT-29 cells. HT-29 cells were incubated for $24 \mathrm{~h}$ with 0 or $250 \mu \mathrm{g} / \mathrm{ml}$ fucoidan and lysed with or without stimulation with IGF-I $(10 \mathrm{nM})$ for $0,5,30$ or $60 \mathrm{~min}$. Total cell lysates $(0.90 \mathrm{mg}$ total protein) were incubated with anti-IRS-1 antibody and the immune complexes were precipitated with protein A-agarose beads. The immunoprecipitated proteins were analyzed with western blot analysis with antibodies against p-Tyr, IRS-1 or PI3K p85. IGF, insulin-like growth factor; IRS-1, insulin receptor substrate-1; PI3K, phosphatidylinositol 3-kinase.

the IGF-IR signaling pathway. Levels of p-IGF-IR/IGF-IR and p-AKT/AKT increased in control cells in a time-dependent manner with IGF-I stimulation (Fig. 6). Fucoidan treatment delayed p-IGF-IR/IGF-IR and p-AKT/AKT expression for up to $60 \mathrm{~min}$, lower than the control cells level. In addition, in the control group, p-ERK/ERK increased with IGF-I stimulation without changing total ERK levels. There were no differences in $\mathrm{p}$-ERK/ERK1/2 expression in the fucoidan treatment group.

\section{Discussion}

Colon cancer is one of the most common cancers in both men and women and is prevalent worldwide $(1,2)$. Globally, the incidence of colon cancer is increasing, seemingly due to changes in dietary habits and preferences. Dietary habits can affect the development of colon cancer, and food ingredients may serve as chemotherapeutic agents $(22,24,38-43)$. Many studies have investigated potential colon cancer treatments. Some studies have suggested marine natural products with pharmacological activities as a method for treating colon cancer (44). Among these marine natural products, seaweeds have been reported to contain various useful compounds such as laminarin, fucoidan, dactylone, and meroditerpenoids with various effects in cancer cells (37-44). Numerous studies have investigated the effects of seaweeds on cell death pathways including apoptosis. The inhibition of apoptosis in colon cancer cells promotes tumor growth and tumor progression and imparts tolerance to cytotoxic anticancer drugs $(7,22,23,27,40-43)$.

Studies related to colon cancer have found that laminarin inhibits cancer cells via Fas and IGF-IR signaling through the intrinsic apoptotic and ErbB pathways, and induces Fas-mediated apoptosis by regulating Fas and Fas-associated protein with death domain (FADD) protein levels (34,45-47). Fucoidan suppressed growth, decreased metastasis, inhibited angiogenesis, and induced apoptosis through activated caspases, resulting in the induction of apoptosis through both death receptor-mediated and mitochondria-mediated apoptotic pathways $(22,38,40-43)$. Dactylone also induced G1-S cell cycle arrest and apoptosis in tumor cells (44).

In previous studies, fucoidan induced apoptosis through the apoptotic pathway and cytotoxicity, and inhibited migration and proliferation in HT-29 colon cancer cells
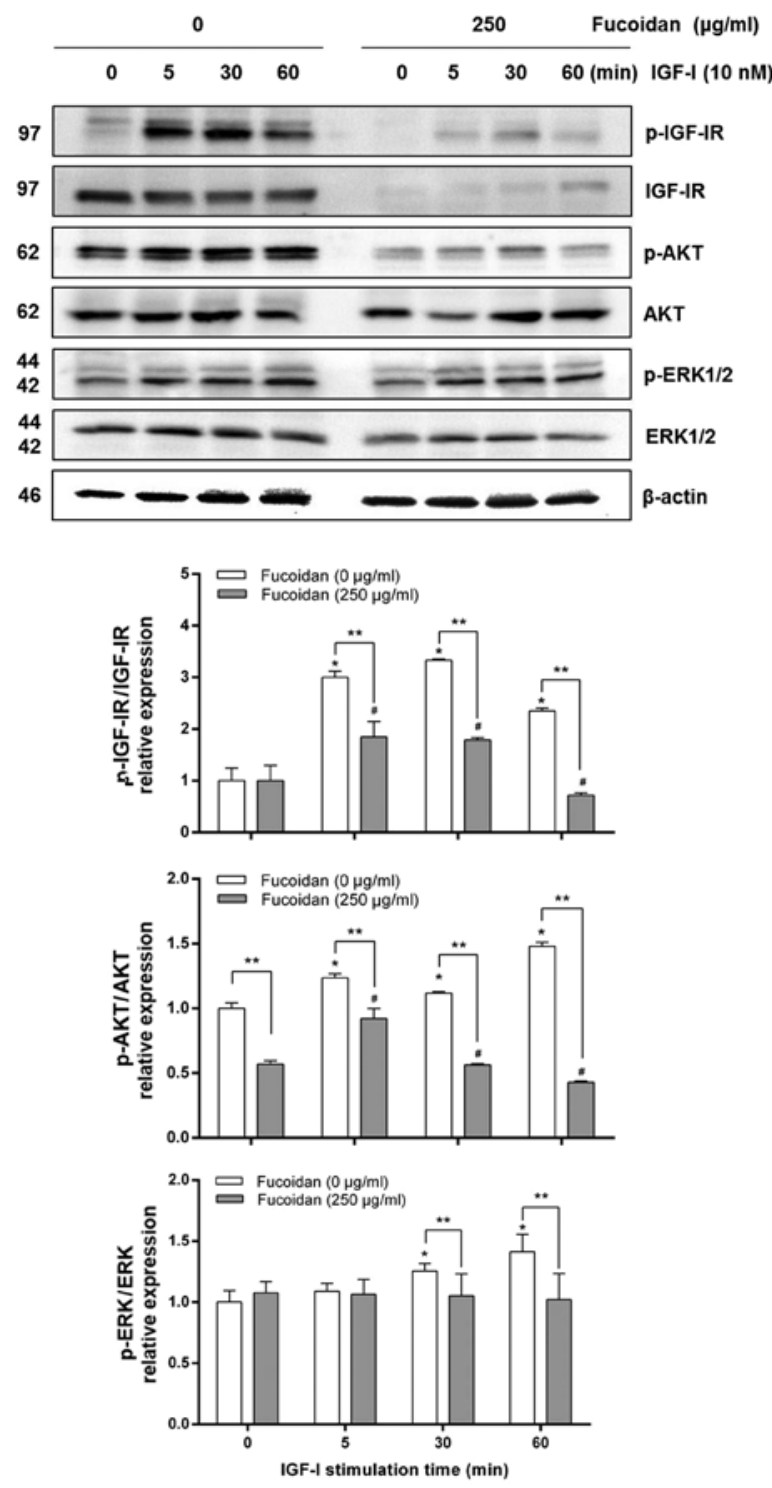

Figure 6. Fucoidan reduces the levels of phosphorylated IGF-IR, AKT, and ERK in IGF-I-stimulated HT-29 cells. HT-29 cells were incubated for $24 \mathrm{~h}$ with 0 or $250 \mu \mathrm{g} / \mathrm{ml}$ fucoidan and lysed with or without stimulation with IGF-I $(10 \mathrm{nM})$ for $0,5,30$ or $60 \mathrm{~min}$. Total cell proteins were analyzed with antibodies against IGF-IR, AKT, and ERK using western blot analsysis. Data were analyzed using two-way analysis of variance. ${ }^{*} \mathrm{P}<0.05$ vs. fucoidan $(0 \mu \mathrm{g} / \mathrm{ml})(0 \mathrm{~min}) ;{ }^{\#} \mathrm{P}<0.05$ vs. fucoidan $(250 \mu \mathrm{g} / \mathrm{ml})(0 \mathrm{~min}) ;{ }^{* *} \mathrm{P}<0.05$ vs. fucoidan $(0 \mu \mathrm{g} / \mathrm{ml})$ (same time). (Values at the left of the western blot indicate the molecular weights of the proteins in $\mathrm{kDa}$ ).

$(22,24,28,40,42,43)$. Fucoidan exerted an anticancer effect by downregulating the PI3K-AKT-mTOR signaling pathway (40). In the present study, we investigated the downregulation of IGF signaling pathways by fucoidan in HT-29 cells.

The present study provided the first evidence that fucoidan reduces IGF-IR protein expression and IGF-IR-mediated signaling through the IRS-1/PI3K/AKT pathway. We examined cell proliferation using a cell viability assay kit with various concentrations of fucoidan $(0-1,000 \mu \mathrm{g} / \mathrm{ml})$. The results indicated that fucoidan inhibited cell proliferation in a dose-dependent manner in HT-29 cells (Fig. 1).

IGF signaling plays a vital role in promoting normal cell proliferation, tumorigenesis, and cancer cell proliferation. IGF-I is also known to inhibit cell death and promote growth 
in various cancer cells, including colon cancer cells. IGF-IR expression is increased in colon cancer compared to normal mucosal tissues (48). In the present study, we investigated whether the anticancer effects of fucoidan involve changes in the IGF-IR signaling pathway. The IGF-IR-related pathway can be divided into two main downstream signaling pathways: The IRS-1/PI3K/AKT and Ras/Raf/ERK pathways $(35,36)$. In the IRS-1/PI3K/AKT pathway, the protein expression of pathway members, including IGF-IR, PTEN, PI3K, and AKT, decreased in a concentration-dependent manner upon fucoidan treatment (Fig. 2). The protein expression of Ras/Raf/ERK pathway members, including IGF-IR, Shc, Ras, SOS, Grab2, Raf, and MEK, also decreased in a concentration-dependent manner (Fig. 3).

The present study suggests that fucoidan inhibits phosphorylation of the $\beta$-subunit of IGF-IR by downregulating the $\alpha$-subunit, directly interfering with the binding of IGF-I to IGF-IR. In immunoprecipitation assays and western blot analysis, fucoidan reduced IGF-I-induced tyrosine phosphorylation of IGF-IR and IRS-1, leading to reduced interaction between PI3K p85 and IGF-IR $\beta$, and the subsequent activation of PI3K/AKT but not ERK1/2 (Figs. 4-6). AKT plays a vital role in PI3K-mediated suppression of cell proliferation as a downstream target of the PI3K/AKT pathway $(28,40,49)$. We found that fucoidan inhibited IGF-I-induced activation of AKT, which may have been due to reduced IGF-IR levels and the subsequent reduction in IGF-IR activation. The moderate reduction in AKT protein levels may also have contributed to the reduced p-AKT levels (Fig. 6). However, fucoidan did not affect IGF-I-induced activation of p-ERK/ERK levels. Fucoidan was also partially associated with the Ras/Raf pathway in the Ras/Raf/ERK pathway.

Recent data indicate that fucoidan triggers G1 phase arrest and apoptosis in HCT116 colon cancer cells through a p53-independent pathway. In particular, it has been suggested that fucoidan is able to enhance p21 expression at transcriptional level in a p53-independent manner (50). IGF-I signaling is strongly associated with cell growth and has a significant role in ribosome biogenesis by regulating the expression of proteins directly involved in the processing of ribosomal subunits and p53-mediated regulation of cell cycle progression (51). In particular, IGF-I activates the murine double minute 2 (MDM2) protein which is a component crucial regulator of cell proliferation and apoptosis and acts in association to some ribosomal proteins by inhibiting the $\mathrm{p} 53$ tumor suppressor (51). It has been demonstrated that fucoidan is able to synergize with standard anticancer agents as 5-FU and reduce its toxicity $(52,53)$. Recent data showed that in HCT116 colon cancer cells 5-FU is able to induce perturbation of ribosome biogenesis led to nucleolar stress (52). This condition activates p53 independent pathway involving ribosomal proteins and MDM2 leading to p21-mediated cell cycle arrest and apoptosis. In previous study, fucoidan were induced G1 phase arrest and apoptosis in p53 mutated colon cancer cell line, HT-29 (23). In present study, we examined whether HT-29 cells affect the IGF-IR singnaling pathway involved in cell proliferation during fucoidan. In this result, an interesting possiblility may be that fucoidan through the IGF-I signlaing could activate ribosomal protein/MDM2/ p21 induced cell death. The research on this is expected to be further progressed.
Based on these findings, we conclude that fucoidan inhibits cell proliferation and induces apoptosis by inhibiting the IGF-I-induced IGF-IR signaling pathway, including the IRS-1/P13K/AKT pathway, in HT-29 cells. These results suggest that downregulation of IGF-IR/IRS-1/PI3K/AKT signaling may be one of the mechanisms by which fucoidan impacts HT-29 cells. These results suggest that the anti-proliferative effect of fucoidan may be mediated through downregulation of the IGF-I/IGF-IR/IRS-1/PI3K/AKT signaling pathway. Therefore, fucoidan may be useful as a chemopreventive agent in colon cancer cells.

\section{Acknowledgements}

This study was supported by Pukyong National University (grant no. C-D-2016-0267), Busan, Republic of Korea.

\section{References}

1. Alwarsamy M, Gooneratne R and Ravichandran R: Effect of fucoidan from Turbinaria conoides on human lung adenocarcinoma epithelial (A549) cells. Carbohydr Polym 152: 207-213, 2016.

2. Siegel R, Desantis C and Jemal A: Colorectal cancer statistics, 2014. CA Cancer J Clin 64: 104-117, 2014.

3. Hayat MJ, Howlader N, Reichman ME and Edwards BK: Cancer statistics, trends, and multiple primary cancer analyses from the Surveillance, Epidemiology, and End Results (SEER) Program. Oncologist 12: 20-37, 2007.

4. Li B, Lu F, Wei X and Zhao R: Fucoidan: Structure and bioactivity. Molecules 13: 1671-1695, 2008.

5. Bilan MI, Grachev AA, Ustuzhanina NE, Shashkov AS, Nifantiev NE and Usov AI: Structure of a fucoidan from the brown seaweed Fucus evanescens C.Ag. Carbohydr Res 337: 719-730, 2002.

6. Chen A, Lan Y, Liu J, Zhang F, Zhang L, Li B and Zhao X: The structure property and endothelial protective activity of fucoidan from Laminaria japonica. Int J Biol Macromol 105: 1421-1429, 2017.

7. Moussavou G, Kwak DH, Obiang-Obonou BW, Maranguy CA, Dinzouna-Boutamba SD, Lee DH, Pissibanganga OG, Ko K, Seo JI and Choo YK: Anticancer effects of different seaweeds on human colon and breast cancers. Mar Drugs 12: 4898-4911, 2014.

8. Yang WN, Chen PW and Huang CY: Compositional characteristics and in vitro evaluations of antioxidant and neuroprotective properties of crude extracts of fucoidan prepared from compressional puffing-pretreated Sargassum crassifolium. Mar Drugs 15: E183, 2017.

9. Palanisamy S, Vinosha M, Marudhupandi T, Rajasekar P and Prabhu NM: In vitro antioxidant and antibacterial activity of sulfated polysaccharides isolated from Spatoglossum asperum. Carbohydr Polym 170: 296-304, 2017.

10. Palanisamy S, Vinosha M, Marudhupandi T, Rajasekar P and Prabhu NM: Isolation of fucoidan from Sargassum polycystum brown algae: Structural characterization, in vitro antioxidant and anticancer activity. Int J Biol Macromol 102: 405-412, 2017.

11. Phull AR, Majid M, Haq IU, Khan MR and Kim SJ: In vitro and in vivo evaluation of anti-arthritic, antioxidant efficacy of fucoidan from Undaria pinnatifida (Harvey) Suringar. Int J Biol Macromol 97: 468-480, 2017.

12. Ryu MJ and Chung HS: Fucoidan reduces oxidative stress by regulating the gene expression of HO 1 and SOD 1 through the Nrf2/ERK signaling pathway in HaCaT cells. Mol Med Rep 14: 3255-3260, 2016.

13. Heeba GH and Morsy MA: Fucoidan ameliorates steatohepatitis and insulin resistance by suppressing oxidative stress and inflammatory cytokines in experimental non-alcoholic fatty liver disease. Environ Toxicol Pharmacol 40: 907-914, 2015.

14. RuiX,Pan HF, Shao SL and Xu XM: Anti-tumor and anti-angiogenic effects of Fucoidan on prostate cancer: Possible JAK-STAT3 pathway. BMC Complement Altern Med 17: 378, 2017.

15. Liu F, Luo G, Xiao Q, Chen L, Luo X, Lv J and Chen L: Fucoidan inhibits angiogenesis induced by multiple myeloma cells. Oncol Rep 36: 1963-1972, 2016. 
16. Zhang Z, Till S, Jiang C, Knappe S, Reutterer S, Scheiflinger F, Szabo CM and Dockal M: Structure-activity relationship of the pro- and anticoagulant effects of Fucus vesiculosus fucoidan. Thromb Haemost 111: 429-437, 2014.

17. Cumashi A, Ushakova NA, Preobrazhenskaya ME, D'Incecco A, Piccoli A, Totani L, Tinari N, Morozevich GE, Berman AE, Bilan MI, et al; Consorzio Interuniversitario Nazionale per la Bio-Oncologia, Italy: A comparative study of the anti-inflammatory, anticoagulant, antiangiogenic, and antiadhesive activities of nine different fucoidans from brown seaweeds Glycobiology 17: 541-552, 2007.

18. Shen HY, Li LZ, Xue KC, Hu DD and Gao YJ: Antitumor activity of fucoidan in anaplastic thyroid cancer via apoptosis and anti-angiogenesis. Mol Med Rep 15: 2620-2624, 2017.

19. Hsu HY, Lin TY, Lu MK, Leng PJ, Tsao SM and Wu YC: Fucoidan induces Toll-like receptor 4-regulated reactive oxygen species and promotes endoplasmic reticulum stress-mediated apoptosis in lung cancer. Sci Rep 7: 44990, 2017.

20. Xue M, Ji X, Xue C, Liang H, Ge Y, He X, Zhang L, Bian K and Zhang L: Caspase-dependent and caspase-independent induction of apoptosis in breast cancer by fucoidan via the PI3K/AKT/GSK $3 \beta$ pathway in vivo and in vitro. Biomed Pharmacother 94: 898-908, 2017.

21. Cho Y, Cho EJ, Lee JH, Yu SJ, Kim YJ, Kim CY and Yoon JH: Fucoidan-induced ID-1 suppression inhibits the in vitro and in vivo invasion of hepatocellular carcinoma cells. Biomed Pharmacother 83: 607-616, 2016.

22. Somasundaram SN, Shanmugam S, Subramanian B and Jaganathan R: Cytotoxic effect of fucoidan extracted from Sargassum cinereum on colon cancer cell line HCT-15. Int J Biol Macromol 91: 1215-1223, 2016.

23. Kim IH, Kwon MJ and Nam TJ: Differences in cell death and cell cycle following fucoidan treatment in high-density HT-29 colon cancer cells. Mol Med Rep 15: 4116-4122, 2017.

24. Han MH, Lee DS, Jeong JW, Hong SH, Choi IW, Cha HJ, Kim S, Kim HS, Park C, Kim GY, et al: Fucoidan induces ROS-dependent apoptosis in 5637 human bladder cancer cells by downregulating telomerase activity via inactivation of the PI3K/Akt signaling pathway. Drug Dev Res 78: 37-48, 2017.

25. Xue M, Ge Y, Zhang J, Liu Y, Wang Q, Hou L and Zheng Z: Fucoidan inhibited 4T1 mouse breast cancer cell growth in vivo and in vitro via downregulation of $\mathrm{Wnt} / \beta$-catenin signaling. Nutr Cancer 65: 460-468, 2013

26. Park HY, Kim GY, Moon SK, Kim WJ, Yoo YH and Choi YH: Fucoidan inhibits the proliferation of human urinary bladder cancer T24 cells by blocking cell cycle progression and inducing apoptosis. Molecules 19: 5981-5998, 2014.

27. Han YS, Lee JH and Lee SH: Antitumor effects of fucoidan on human colon cancer cells via activation of Akt signaling. Biomol Ther (Seoul) 23: 225-232, 2015.

28. Yang G, Zhang Q, Kong Y, Xie B, Gao M, Tao Y, Xu H, Zhan F, Dai B, Shi J, et al: Antitumor activity of fucoidan against diffuse large B cell lymphoma in vitro and in vivo. Acta Biochim Biophys Sin (Shanghai) 47: 925-931, 2015.

29. Atashrazm F, Lowenthal RM, Woods GM, Holloway AF, Karpiniec SS and Dickinson JL: Fucoidan suppresses the growth of human acute promyelocytic leukemia cells in vitro and in vivo. J Cell Physiol 231: 688-697, 2016.

30. Scagliotti GV and Novello S: The role of the insulin-like growth factor signaling pathway in non-small cell lung cancer and other solid tumors. Cancer Treat Rev 38: 292-302, 2012.

31. Xu L, Zhou R, Yuan L, Wang S, Li X, Ma H, Zhou M, Pan C, Zhang J, Huang N, et al: IGF1/IGF1R/STAT3 signaling-inducible IFITM2 promotes gastric cancer growth and metastasis. Cancer Lett 393: 76-85, 2017

32. Frasca F, Pandini G, Sciacca L, Pezzino V, Squatrito S, Belfiore A and Vigneri R: The role of insulin receptors and IGF-I receptors in cancer and other diseases. Arch Physiol Biochem 114: 23-37, 2008.

33. Park HK, Kim IH, Kim J and Nam TJ: Induction of apoptosis by laminarin, regulating the insulin-like growth factor-IR signaling pathways in HT-29 human colon cells. Int J Mol Med 30: 734-738, 2012.
34. Lee HS, Cho HJ, Kwon GT and Park JH: Kaempferol downregulates insulin-like growth factor-I receptor and ErbB3 signaling in HT-29 human colon cancer cells. J Cancer Prev 19: 161-169, 2014.

35. Fidler MJ, Shersher DD, Borgia JA and Bonomi P: Targeting the insulin-like growth factor receptor pathway in lung cancer: Problems and pitfalls. Ther Adv Med Oncol 4: 51-60, 2012.

36. Yu H and Rohan T: Role of the insulin-like growth factor family in cancer development and progression. J Natl Cancer Inst 92: 1472-1489, 2000.

37. Vishchuk OS, Sun H, Wang Z, Ermakova SP, Xiao J, Lu T, Xue P, Zvyagintseva TN, Xiong $\mathrm{H}$, Shao C, et al: PDZ-binding kinase/T-LAK cell-originated protein kinase is a target of the fucoidan from brown alga Fucus evanescens in the prevention of EGF-induced neoplastic cell transformation and colon cancer growth. Oncotarget 7: 18763-18773, 2016

38. Kim EJ, Kang IJ, Cho HJ, Kim WK, Ha YL and Park JH: Conjugated linoleic acid downregulates insulin-like growth factor-I receptor levels in HT-29 human colon cancer cells. J Nutr 133: 2675-2681, 2003.

39. Pollak MN, Schernhammer ES and Hankinson SE: Insulin-like growth factors and neoplasia. Nat Rev Cancer 4: 505-518, 2004.

40. Han YS, Lee JH and Lee SH: Fucoidan inhibits the migration and proliferation of HT-29 human colon cancer cells via the phosphoinositide-3 kinase/Akt/mechanistic target of rapamycin pathways. Mol Med Rep 12: 3446-3452, 2015.

41. Thinh PD, Menshova RV, Ermakova SP, Anastyuk SD, Ly BM and Zvyagintseva TN: Structural characteristics and anticancer activity of fucoidan from the brown alga Sargassum mcclurei. Mar Drugs 11: 1456-1476, 2013.

42. Kim EJ, Park SY, Lee JY and Park JH: Fucoidan present in brown algae induces apoptosis of human colon cancer cells. BMC Gastroenterol 10: 96, 2010.

43. Hyun JH, Kim SC, Kang JI, Kim MK, Boo HJ, Kwon JM, Koh YS, Hyun JW, Park DB, Yoo ES, et al: Apoptosis inducing activity of fucoidan in HCT-15 colon carcinoma cells. Biol Pharm Bull 32: 1760-1764, 2009.

44. Fedorov SN, Shubina LK, Bode AM, Stonik VA and Dong Z: Dactylone inhibits epidermal growth factor-induced transformation and phenotype expression of human cancer cells and induces G1-S arrest and apoptosis. Cancer Res 67: 5914-5920, 2007.

45. Park HK, Kim IH, Kim J and Nam TJ: Induction of apoptosis and the regulation of ErbB signaling by laminarin in HT-29 human colon cancer cells. Int J Mol Med 32: 291-295, 2013

46. Ji CF and Ji YB: Laminarin-induced apoptosis in human colon cancer LoVo cells. Oncol Lett 7: 1728-1732, 2014.

47. Ji YB, Ji CF and Zhang $\mathrm{H}$ : Laminarin induces apoptosis of human colon cancer LOVO cells through a mitochondrial pathway. Molecules 17: 9947-9960, 2012.

48. Guo YS, Narayan S, Yallampalli C and Singh P: Characterization of insulinlike growth factor I receptors in human colon cancer. Gastroenterology 102: 1101-1108, 1992.

49. Franke TF, Kaplan DR and Cantley LC: PI3K: Downstream AKTion blocks apoptosis. Cell 88: 435-437, 1997.

50. Park HY, Park SH, Jeong JW, Yoon D, Han MH, Lee DS, Choi G, Yim MJ, Lee JM, Kim DH, et al: Induction of p53-independent apoptosis and G1 cell cycle arrest by fucoidan in HCT116 human colorectal carcinoma cells. Mar Drugs 15: E154, 2017.

51. Worrall C, Suleymanova N, Crudden C, Trocoli Drakensjö I, Candrea E, Nedelcu D, Takahashi SI, Girnita L and Girnita A: Unbalancing $\mathrm{p} 53 / \mathrm{Mdm} 2 / \mathrm{IGF}-1 \mathrm{R}$ axis by Mdm2 activation restrains the IGF-1-dependent invasive phenotype of skin melanoma. Oncogene 36: 3274-3286, 2017.

52. Pagliara V, Saide A, Mitidieri E, d'Emmanuele di Villa Bianca R, Sorrentino R, Russo G and Russo A: 5-FU targets rpL3 to induce mitochondrial apoptosis via cystathionine- $\beta$-synthase in colon cancer cells lacking p53. Oncotarget 7: 50333-50348, 2016.

53. Russo A, Saide A, Cagliani R, Cantile M, Botti G and Russo G: rpL3 promotes the apoptosis of p53 mutated lung cancer cells by down-regulating $\mathrm{CBS}$ and $\mathrm{NF} \kappa \mathrm{B}$ upon 5-FU treatment. Sci Rep 6: 38369, 2016. 